\title{
87.
}

\section{NOTES ON ELLIPTIC FUNCTIONS (FROM JACOBI).}

[From the Cambridge and Dublin Mathematical Journal, vol. v. (1850), pp. 201-204.]

These Notes are mere translations from Jacobi's "Note sur une nouvelle application de l'analyse des fonctions elliptiques à l'algèbre," [Crelle, t. vIr. (1831) pp. 41-43], and from the addition to the notice by him of the third supplement to Legendre's "Théorie des fonctions elliptiques" [Crelle, t. viIr. (1832) pp. 413-417]. 